\title{
Correction: Case of primary bilateral diffuse large B-cell lymphoma of the ovary with plasmablastic features in an HIV- negative female patient
}

Guvvala SL, Sakam S, Niazi M, et al. Case of primary bilateral diffuse large B-cell lymphoma of the ovary with plasmablastic features in an HIV-negative female patient. BMJ Case Rep 2017;2017. doi: 10.1136/bcr-2016-218117

A new author has been added to the article: 'Ioannis Alagkiozidis; Division of Obstetrics and Gynecology, Bronx-Lebanon Hospital Center, Bronx, New York, USA'.

In Summary section, the sentences "A 37-year-old woman from Puerto Rico presented to our clinic with symptoms of an abdominal distension progressively worsening over 1 year. A CT of an abdomen and pelvis with contrast was performed and revealed bilateral large heterogeneous pelvic adnexal masses with large ascites and right pleural effusion." should read: "A 37-year-old woman from Puerto Rico was incidentally found to have bilateral ovarian masses during a laparoscopy for sterilization. CT of the abdomen and pelvis with contrast showed bilateral large heterogeneous adnexal masses with large ascites and right pleural effusion."

In Summary section, the sentence "She underwent total abdominal hysterectomy, bilateral salpingo-oophorectomy with pelvic lymph node dissection and partial omentectomy." should read: "She underwent total laparoscopy hysterectomy, bilateral salpingo-oophorectomy with pelvic lymph node dissection and partial omentectomy."

In Case Presentation, the sentence "A 37-year-old woman gravida 9, para 6, was found to have abdominal distension during an office visit." should read: "A 37-year-old woman gravida 9 , para 6, was incidentally found to have bilateral ovarian masses during a laparoscopy for sterilization."

In Investigation section, the sentences "The patient underwent total abdominal hysterectomy with bilateral salpingo-oophorectomy along with partial omentectomy and pelvic lymph node dissection (figure 2). The frozen section was suggestive of lymphoma. The peritoneum, liver and other adjacent organs were not involved macroscopically." should read: "After draining the large right pleural effusion with chest tube, the patient underwent a diagnostic laparoscopy with drainage of the ascites, total laparoscopic hysterectomy with bilateral salpingo-oophorectomy, partial omentectomy and pelvic lymph node dissection (figure 2). Frozen section showed malignancy of unknown primary site and decision was made to complete surgical staging for possible primary ovarian carcinoma. The peritoneum, liver and other adjacent organs were not involved macroscopically.”

Figure 2 caption has been changed from "A laparoscopic picture showing bilateral abdominal tumours and a thickened omentum" to "A laparoscopic picture showing bilateral ovarian tumours."

Acknowledgement section has been removed from the article.

In Contributors section, the following statement "IA contributed to the operative portion of the manuscript, figures and revised the article" has been added.

(C) Author(s) (or their employer(s)) 2019. No commercial re-use. See rights and permissions. Published by BMJ.

BMJ Case Rep 2019;12:e218117corr1. doi:10.1136/bcr-2016-218117corr1

Check for updates

Copyright 2019 BMJ Publishing Group. All rights reserved. For permission to reuse any of this content visit https://www.bmj.com/company/products-services/rights-and-licensing/permissions/ BMJ Case Report Fellows may re-use this article for personal use and teaching without any further permission.

Become a Fellow of BMJ Case Reports today and you can:

- Submit as many cases as you like

- Enjoy fast sympathetic peer review and rapid publication of accepted articles

- Access all the published articles

- Re-use any of the published material for personal use and teaching without further permission

Customer Service

If you have any further queries about your subscription, please contact our customer services team on $+44(0)$ 2071111105 or via email at support@bmj.com.

Visit casereports.bmj.com for more articles like this and to become a Fellow 